\title{
AN INVESTIGATION INTO THE GENERIC LIMITS OF DALBERGIA AND MACHAERIUM (PAPILIONACEAE)
}

\author{
T. BARETTA-KUIPERS
}

Instituut voor Systematische Plantkunde, Utrecht

\section{SUMMARY}

Dalbergia and Machaerium are two distinct genera. The former genus Ecastophyllum is a distinct entity in the genus Dalbergia. The former genus Drepanocarpus differs from Machaerium only in certain pod characters and is considered as congeneric with it.

\section{INTRODUCTION}

In the literature the main difference between the genera Dalbergia and Machaerium is said to be the method of dehiscence of the anthers (Bentham, Ducke, Burkart, Amshoff). Such a character, if used by itself, would appear rather trivial. Moreover, as there seemed to be several transitions between the genera, it seemed worthwhile to investigate whether other characters are associated with the anther character, or, in other words, if the delimitation of the genera would have to be revised or even abandoned. Most modern authors, i.a. DuCKE (1922), AmShoff (1939), Hoenne (1941), recognize only the genera Dalbergia and Machaerium, whereas HUTCHINSON in his recent work (1964) again subdivides Machaerium into Machaerium and Drepanocarpus, as was done by some older authors, e.g., Bentham (1860). Machaerium is, with the exclusion of one species, entirely neotropical, Dalbergia occurs in the tropics and subtropics all over the world. In Dalbergia 60 species were available for study out of a total of about 100, in Machaerium 53 out of a total of about 120 species. For both genera this is about half of the number of species. As the investigated characters are so consistent, it seemed justified to draw conclusions valid for the genus as a whole though based only on the species investigated.

The material was taken from the herbaria of Utrecht and Wageningen. Where the material was incomplete, I tried to supplement the data from the original description, which was, however, not always sufficient. Particular attention was paid to characters of leaf and leaflets, indument, stipules, inflorescence, size of flower, length of pedicel, calyx, corolla, stamens, anthers, style, ovary, and pod. The data were marked on punchcards, one for each species. In this way correlations between diverse characters could be readily observed. 


\section{RESULTS}

It appears that several characters occur either in Machaerium or in Dalbergia. In the following list, characters applying to all species investigated are printed in bold face, those applying to most species in roman, those applying to some species in italics.

\section{Machaerium}

calyx teeth about similar in shape and size

calyx teeth shorter than $1 / 5$ of calyx tube (25 spp.)

vexillum hirsute (44 spp.)

vexillum glabrous ( 9 spp.)

anthers versatile

anthers dehiscing with longitudinal slits

anthers oblong, large (39 spp.)

anthers globular or triangular $(9$

spp.)

disc present (28 spp.)

pod unilaterally alate (37 spp.)

pod orbicular or oval (5 spp.)

pod intermediate ( 3 spp.)

seed excentric in the pod

leaflets parallel-veined (17 spp.)

leaves with more than 20 leaflets $(19$ spp.)

stipules thickened into a spine (26

spp.)

flowers sessile (21 spp.)

inflorescence exclusively terminal (16 spp.)

\author{
Dalbergia \\ calyx teeth dissimilar in shape and size, \\ never shorter than $1 / 4$ of calyx tube \\ calyx teeth as long as calyx tube \\ vexillum glabrous \\ anthers non-versatile \\ anthers dehiscing with small, trans- \\ verse slits \\ anthers globular, small
}

\author{
dise wanting \\ pod never unilaterally alate
}

seed centrally located in the pod

leaflets reticulate-veined

leaves with less than 20 leaflets (55 spp.)

stipules never thickened into a spine

flowers pedicellate

inflorescence never exclusively terminal

As shown by the table, Dalbergia is much more homogeneous than Machaerium, where few characters are present in all but more in only some species. It should be stated here, since the table does not show it, that Machaerium seems still a natural group, as the deviating species diverge only in one or two characters of importance, whereas the others are always in good agreement with the genus as a whole and exclude them from Dalbergia.

When looking into the question if, apart from the (superficial) similarity in the pods, there is still more resemblance between the former genus Ecastophyllum, now united with Dalbergia, and the former genus Drepanocarpus, now united with Machaerium, the following becomes apparent: between Dalbergia riedelii, D. subcymosa, D. monetaria, D. nitida, and D. ecastophyllum there is much mutu- 
al conformity. The most striking character is that they have the stamens in two groups of four and five, respectively: isadelphous with nine stamens. This was not found in a single other Dalbergia species. In this group only Dalbergia ecastophyllum is isadelphous with 10 stamens. Another conspicuous property of the species of this group is that they have few leaflets, viz. from one to five, only in D. subcymosa about 10. In the former genus Drepanocarpus only Machaerium ferox is isadelphous, the other species, viz. $M$. inundatum, $M$. crista-castrense, $M$. lunatum, and $M$. aristulatum, are monadelphous with 10 stamens. Except for the (superficial) likeness of the pods they have little in common with the former genus Ecastophyllum, at least in the characters I have taken into consideration. Moreover, they have no close general similarity to each other, apart from the more or less pronounced curvature of the pod.

\section{CONCLUSIONS}

Apart from the dehiscence of the anthers, there are several important features that occur only in Dalbergia, or only in Machaerium, and it seems therefore justified to consider the generic limits of Dalbergia and Machaerium as correct. The main difference between the genera is in the pod.

As far as known to me, in Dalbergia the seed is always situated in about the middle of the pod ( $f i g .1 e, f$ en $g$ ). In Machaerium, however, it is placed in the basal part of the pod which is nearly always unilaterally alate, (fig. la) except in the former genus Drepanocarpus ( $f$ ig. $1 d$ ) with a few intermediate forms ( $f g . l b$ and $c$ ). The pod is always more or less incurved towards the seed.

The shape of the anthers is in Dalbergia always globular and in Machaerium mostly oblong. As a rule the anthers in Machaerium are rather large; there are, however, also species with quite small ones.

There are also characteristic differences in the calyx, not only as regards the shape in bud (in Dalbergia it is campanulate and in Machaerium obtuse and tubular), but also in the shape and size of the calyx teeth. In Dalbergia they are nearly always dissimilar in shape and size, in Machaerium mostly nearly identical. In Machaerium the flowers are sessile in about half of the investigated species, in Dalbergia in one species only. A character emphasizing the difference between the genera is the consistency of the flower, of which I got an impression from herbarium material: in Dalbergia calyx and corolla (this is particularly noticeable in the vexillum) are limp and thin, in Machaerium as a rule the calyx is much firmer and sometimes even hard, as is the vexillum.

The former genus Ecastophyllum fits altogether into the picture of the genus Dalbergia, but its species also show a striking mutual similarity in the insertion and number of the stamens (4-5), which does not occur in any other Dalbergia species. They also have few leaflets (1-10, mostly less than five), which occurs occasionally elsewhere in the genus.

The former genus Drepanocarpus has a pod that is different from that of the other Machaerium species. By its other characters, however, it fits well into the genus. When one considers the strong curvature of the pod (fig. 1d) as an ex- 


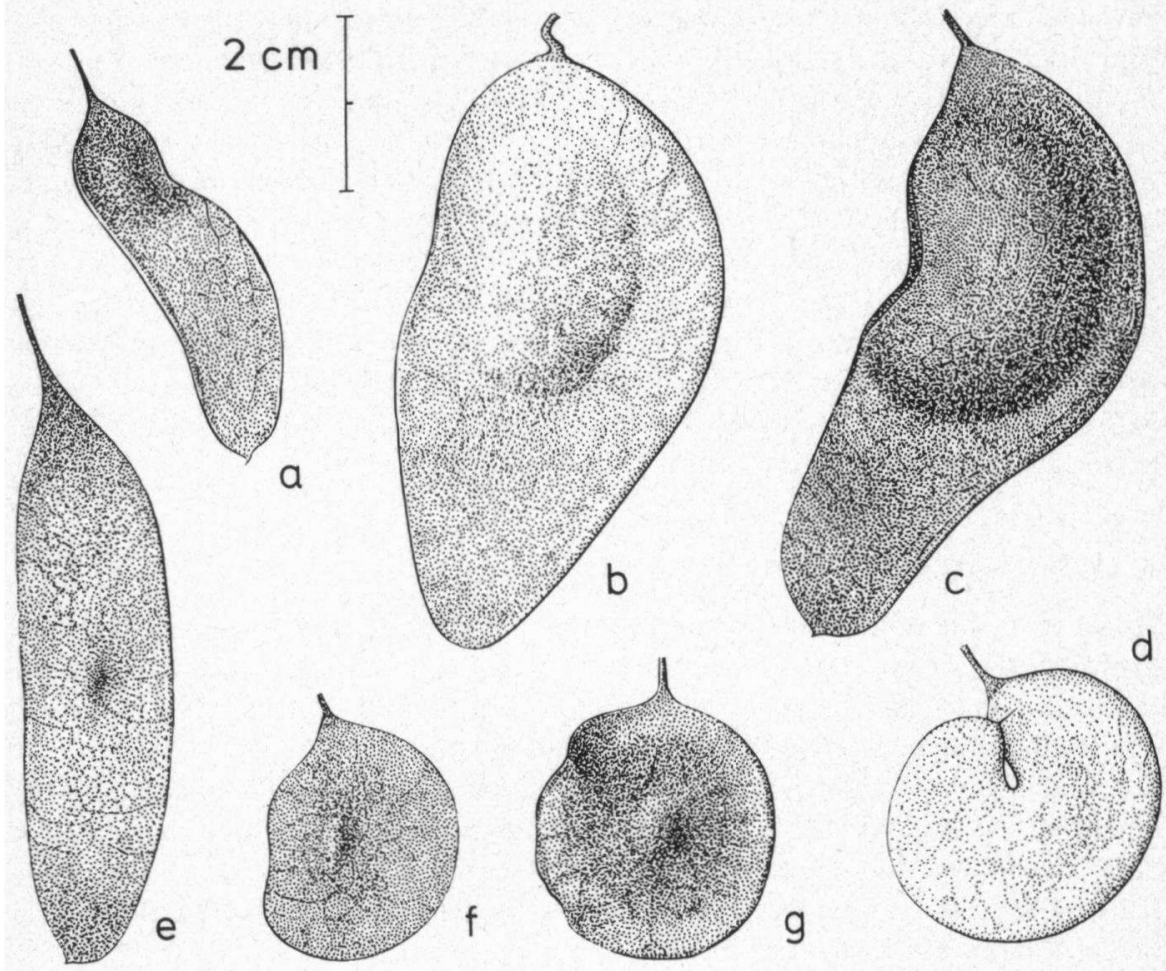

Fig. 1. a. Machaerium stipitatum Vog., Minas Gerais, Brazil (Y. Mexía 4908)

b. M. leiophyllum (DC.) Benth., Pará, Brazil (Ducke 11759)

c. M. trifoliatum Ducke, Suriname (Wessels Boer 1300)

d. M. Iunatum (L.f.) Ducke, Suriname (coll.indig. 1910)

e. Dalbergia spruceana Benth., Amazonas, Brazil (Krukoff 4921)

f. D. ecastophyllum (L.) Taub., Tobago, W. Indies (Broadway 4088)

g. D. monetaria L.f., Suriname (Soeprato 299)

treme degree of curvature towards the seed, as is more weakly the case in the pods of other Machaerium species, there is no need for separating Drepanocarpus from Machaerium, the more so as there are transitions between both types of pod (see fig. lc). DuCKE (1922) described several intermediate shapes of pod, i.a. in $M$. leiophyllum (fig. $1 b$ ) and $M$. macrophyllum, and stated that because of these it is impossible to maintain Drepanocarpus as a separate genus. I quite agree with him and disagree with HuTCHINSON (1964), who again made it a distinct genus. He placed Machaerium in the tribe Pterocarpeae, Dalbergia, however, as the only genus in the tribe Dalbergieae. The only argument in support of this view is that in the tribe Pterocarpeae the anthers are versatile and in the Dalbergieae non-versatile. The other tribal characters are the same. It seems hazardous to place Dalbergia apart on the basis of a single character, the more so as in a few Machaerium species the anthers are not versatile but basifixed. 


\section{ACKNOWLEDGEMENTS}

The author is much indebted to Dr. K. U. Kramer for his assistance in this investigation and for correcting the English text, and to Mr. H. Rijpkema for his accurate drawings.

\section{MATERIAL STUDIED}

Dalbergia afzeliana D. Don: Portuguese Guinea (Espirito Santo 2047, 2672)

D. amerimnum Benth.: Colombia (H. H. Smith 1750)

D. armata E. Merr.: South Africa (Lanjouw 914)

D. boehmii Taub.: Portuguese Guinea (Espirito Santo 2479)

D. brasiliensis Vog.: Brazil, Santa Catarina (Reitz 4600)

D. candenatensis Prain: Malesia, Sumatra (Achmad 863, Korthals s.n.), Indo-China (Clemens 4372)

D. cearensis Ducke: Brazil, Ceará (Ducke 17158)

D. championii Thun: Malesia, Malay Peninsula (King 6565)

D. confertiflora Benth.: India, Malabar (Stocks s.n.)

D. cumingiana Benth.: Philippines, Luzon (16789)

D. dalzielii Bak.f. : Africa, Nigeria (Bonny 2.77)

D. ecastophyllum (L.) Taub.: Africa, Ivory Coast (Versteegh \& den Outer 694), Liberia (Kunkel 512). Jamaica (Hooke's.n.), British Guiana (Tutin 348), Suriname (Geyskes 186, Kramer \& Hekking 2103), Brazil, Amazonas (Krukoff 4807)

D. ealaensis de Wild.: Africa, Cameroons (Breteler 1801)

D. ferruginea Roxb.: India orientalis (Bentham 343)

D. foliosa Benth.: Bolivia (Steinbach 7134), Argentina (Ducke 20380 and 15449), Brazil, Minas Gerais (Y. Mexía 4484 and 5766)

D. frondosa Roxb.: India orientalis (Bentham 723)

D. glauca (Desv.) Amsh.: Venezuela (Maguire 46991), British Guiana (Jenman 4351), Suriname (Lanjouw 864 and 2003, Lindeman 4311, Pulle 436, Versteeg 625), Brazil, Pará (Ducke 11592 and 12151)

D. glaucescens Mart.: Brazil, Santa Catarina (Reitz 4546)

D. grandibracteata De Wild.: Belgian Congo (Louis 8944)

D. heudelotii Stapf: Africa, Ivory Coast (Versteegh \& den Outer 635, de Wilde 871 and 927 )

D. hostilis Benth.: Africa, Sierra Leone (Morton \& Gledhill 3228), Cameroons (de Wilde 1405), Portuguese Guinea (Espirito Santo 1641), Belgian Congo (Louis 11352)

D. hygrophila (Mart.) Hoehne var. nephrocarpa (Ducke) Hoehne: Brazil, Mato Grosso (Ducke 4566)

D. insularis Pulle: Netherlands New Guinea (Versteeg 1117)

D. inundata Spruce: British Guiana (A. C. Smith 2684), Brazil, Amazonas (Ducke 3228, Fróes 22069, Krukoff 6195 and 6671)

D. lactea Vatke: Africa, Ghana (Boughey 10, 473)

D. lanceolaria L.: Sumatra (Lörzing 5157)

D. latifolia Roxb.: India, Canara (Bentham 622), Java, Madioen (Koorders 4109)

D. laxiflora Michel: Africa, Congo (P. Sita 1598)

D. louisii Cronquist: Africa, Belgian Congo (Leonard 937, Louis 1534, P. Sita 1624)

D. melanoxylon Guill. et Perr.: Africa, Cameroons (de Wilde 3476), Tanganyika (Tanner 1042)

D. mimosella Prain: Philippines, Luzon (Ramos s.n.)

D. monetaria L.f.: Jamaica (Proctor 22628), Venezuela (Steyermark 87342), French Guiana (BAFOG 7821), Suriname (Gonggrijp 2932 and 3533, Lindeman 6263, Wessels Boer 1350)

D. mossambicensis Harms: East Africa, Nyasaland (Stolz 1569 and 1676)

D. nigra (Fr. Allemao) Benth.: Brazil, Minas Gerais (Y. Mexía 4128)

D. nitida (Radlk.) Ducke: Brazil, Amazonas (Ducke 4555)

D. nitidula Welw.: Africa, Congo (Devred 249) 
D. oblongifolia G. Don: Africa, Ivory Coast (de Wilde 920, de Wit 1038, Versteegh \& den Outer 726)

D. obovata E. Mey.: Moçambique (Coomans s.n.), South Africa (Lanjouw 467)

D. oligophylla Bak.: Africa, Cameroons (Breteler c.s. MC 175)

D. pachycarpa Uhlr.: Africa, Cameroons (W. de Wilde 2926)

D. parviflora Roxb.: Malay Peninsula (King 6151), Indonesia, Palembang (3723 H.B.)

D. pinnata Prain: Sikkim Himalaya (5-4-1902), Indo-China (Clemens 3925)

D. reticulata Merr.: Philippines, Luzon (Elmer 18340)

D. riedelii (Radlk.) Sandw.: British Guiana (Sandwith 53), Suriname (Pulle 338, Wessels Boer 1257), Brazil, Amazonas (Black 47.1989, Wurdack 43164)

D. rimosa Roxb.: India, Mount Khasia (J. D. Hooker)

D. riparia Benth.: Brazil, Amazonas (Krukoff 6383, Kuhlmann 2607 and 7165)

D. rostrata Grah.: Java (Backer 17238)

D. rufa G. Don.: Africa, Congo (P. Sita 2759), Portuguese Guinea (Espirito Santo 2102)

D. saxatilis Hook.f.: Africa, Ivory Coast (Versteegh \& den Outer 533 and 558, Leeuwenberg 1924), Portuguese Guinea (Espirito Santo 1882)

D. saxatilis Hook.f. var. preussii (Harms) Cronq.: Africa, Belgian Congo (Corbetier 1643)

D. sissoo Roxb.: India (Tahauinpox 441)

D. spruceana Benth.: Brazil, Amazonas (Black 47-1699, Ducke 1996 and 11567, Krukoff 4921)

D. stipulacea Roxb.: India, Assam (Prain 991), E. Pakistan, Chittagong (Hooker \& Thomson)

D. stuhlmannii Taub.: East Africa, Tanganyika (Tanner 4234)

D. subcymosa Ducke: British Guiana (Cowan 38535), French Guiana (BAFOG 7915), Brazil, Pará (Ducke 11572), Amapá (Pires 51662)

D. tomentosa (Benth.) Taub.: Brazil, Amazonas (Kuhlmann 3066)

D. vaccinifolia Vatke: East Africa, Tanganyika (Tanner 2875 and 3768)

D. variabilis Vog.: Brazil, Rio de Janeiro (Kuhlmann 11730, Lisboa 2628)

D. violacea (Vog.) Malme: Brazil, São Paulo (Ducke 4339), Minas Gerais (Regnell II-70)

Machaerium aculeatum Raddi: Brazil, Rio de Janeiro (Kuhlmann 11730), Minas Gerais (Y. Mexia 4468)

M. acutifolium Vog.: Bolivia (Krukoff 10029), Brazil, Pará (Ducke 11749), Minas Gerais (Y. Mexía 4393)

M. amazonense Hoehne: Brazil, Amazonas (Ducke 24194 and 35516)

M. aristulatum Ducke: Brazil, Amazonas (Krukoff 5904)

M. aureiflorum Ducke: Brazil, Amazonas (Ducke 24193), Pará (Ducke 17172)

M. brasiliense Vog.: Brazil, Rio de Janeiro (Kuhlmann 13388 and 15489)

M. castaneiflorum Ducke: Brazil, Amazonas (Ducke 11753), Pará (Ducke 11752)

M. caudatum Ducke: Brazil, Amazonas (Ducke 23382)

M. cobanense Donn. Smith: Guatemala (v. Türckheim II-1401)

M. crista-castrense (Mart.) Ducke: Brazil, Pará (Ducke 17183, T. Silva 267)

M. cuspidatum Kuhlm. et Hoehne: Peru (Y. Mexía 6456)

M. discolor Vog. : Brazil, Minas Gerais (Y. Mexía 5107)

M. ferox (Benth.) Ducke: British Guiana (Fanshawe 6346), Suriname (Hulk 94 a), Brazil, Amapá (Pires 51483), Amazonas (Kuhlmann 3069)

M. firmum Benth.: Brazil, Rio de Janeiro (Allemao 5067)

M. floribundum Benth.: British Guiana (Fanshawe 5101 and 5192), Brazil, Pará (Ducke 2030 and 11650)

M. floridum (Mart.) Ducke: Brazil, Minas Gerais (Y. Mexía 4724), Rio de Janeiro (Kuhlmann 15485)

M. glabratum Pittier: Colombia (H. H. Smith 2032)

M. gracile Benth.: Brazil, Minas Gerais (Y. Mexía 4425)

M. hoehneanum Ducke: Brazil, Amazonas (Fróes 29558)

M. humboldtianum Vog.: Colombia (H. H. Smith 2026), Venezuela (Breteler 3676)

M. inundatum (Mart.) Ducke: British Guiana (A. C. Smith 2104), Suriname (Lanjouw 1211, 


\section{DALBERGIA AND MACHAERIUM}

Mennega 108), Brazil, Pará (Krukoff 1237)

M. incorruptibile Fr. Allemao: Brazil, Rio de Janeiro (Ducke 19278, Kuhlmann 15482)

M. isadelphum (E. Mey) Amsh.: Suriname (Hostmann 629), Brazil, Minas Gerais (Y. Mexía 4535, Regnell III-463), Rio de Janeiro (Campos 11741)

M. kegelii Meissn.: British Guiana (Fanshawe 5100, A.C. Smith 3233), Suriname (Kegel 1249)

M. latifolium Rusby: Brazil, Amazonas (Ducke 24199), Pará (Ducke 17169 and 17171)

M. leiophyllum (DC.) Benth.: Suriname (Hostmann 256, Versteeg 134), Brazil, Pará (Ducke 11759 and 17189)

M. lilacinum Ducke: Brazil, Pará (Ducke 11754)

M. longifolium Benth.: Brazil, Pará (Ducke 17164)

M. lunatum (L.f.) Ducke: Suriname (Florschütz 911, Jonker 38, Kramer \& Hekking 2362, Lanjouw 3108, Mennega 231)

M. macrophyllum Mart.: Colombia (Black 46-201)

M. microphyllum (E. Mey) Standl.: Venezuela (Wurdack 40991), Brazil, Amazonas (Ducke 24196, Pires 3452), Pará (Ducke 5061)

M. milleflorum Pittier: Colombia (H. H. Smith 2033)

M. moritzianum Benth.: Venezuela (Steyermark 88946), Colombia (H. H. Smith 14)

M. multifoliatum Ducke: Brazil, Amazonas (Krukoff 8510), Mato Grosso (Krukoff 1428)

M. myrianthum Spruce: Brazil, Mato Grosso (Krukoff 1516)

M. nigrum Vog.: Brazil, Minas Gerais (Y. Mexía 4446 and 4501)

M. oblongifolium Vog.: Brazil, Minas Gerais (Y. Mexía 4168 and 5080), Rio de Janeiro (Kuhlmann 2174, Lisboa 2753)

M. paraense Ducke: Fr. Guiana (BAFOG 7830), Brazil, Amapá (Irwin c.s. 47491 and 48208), Pará (Ducke 11673)

M. paraguariense Hassler: Paraguay (Tessmann 6058)

M. parviflorum Benth.: Brazil, Amazonas (Ducke 24200)

M. purpurascens Pittier: Panama (Hunter 512)

M. quinatum (Aubl.) Sandw.: British Guiana (Fanshawe 4845, A.C. Smith 2682), Brazil, Pará (Ducke 17166, Pires 51934), Mato Grosso (Kuhlmann 18199)

M. robiniifolium Vog.: Venezuela (Breteler 3494)

M. secundifforum Mart.: Brazil, Rio de Janeiro (Constantino 5340, Ducke 2623)

M. seemannii Benth. : Panama (Allen 4606, 17347)

M. setulosum Pittier: Mexico (Y. Mexía 9255)

M. stipitatum Vog.: Brazil, Paraná (Hatschbach 9775), Minas Gerais (Y. Mexía 4908 and 5072, Reitz 8351)

M. tobagense Urb.: Tobago (Broadway 2452)

M. tortipes Hoehne: Brazil, Acre (Ducke 24198)

M. trifoliatum Ducke: Suriname (Wessels Boer 1300), Brazil, Pará (Ducke 17188)

M. uncinatum Benth.: Brazil, Rio de Janeiro (Kuhlmann 5094)

M. villosum Vog.: Brazil, Minas Gerais (Ducke 5069)

M. violaceum Vog. : Brazil, Rio de Janeiro (Ducke 2404 and 2405).

\section{REFERENCES}

Amshoff, G. J. H. (1939): On South American Papilionaceae. Thesis, Utrecht: 73 p.

- (1940): Papilionaceae, in: A. Pulle, Flora of Suriname, İ̄-2. Amsterdam: 257 p.

Bentham, G. (1859): Synopsis of Dalbergieae. Journ. Linn. Soc. IV Suppl., London: 128 p.

- (1859-1862): Leguminosae I, in: MARTIUs, Flora Brasiliensis 15(1): 350 p., tab. 1-126. Leipzig.

BURKART, A. (1952): Las Leguminosas Argentinas silvestres y cultivadas. San Isidro: 590 p.

CRONQUist, A. (1954): Dalbergia, in: Flore du Congo belge et du Ruanda-Urundi VI, Bruxelles: 52-75

DucKe, A. (1922): Plantes nouvelles ou peu connues de la région amazonienne II. Arch. Jard. Bot. Rio de Janeiro 3: 3-269. 
- (1925): Plantes nouvelles ou peu connues de la région amazonienne IIL. Arch. Jard. Bot. Rio de Janeiro 4: 1-205.

- (1930): Plantes nouvelles ou peu connues de la région amazonienne IV. Arch. Jard. Bot. Rio de Janeiro 5: 101-187, fig. 1-57.

- (1939): As Leguminosas da Amazonia Brasileira. Rio de Janeiro. 170 pp.

Hoenne, F. C. (1941): Dalbergia, in: Flora Brasilica 25(3): 126 e 127: 33p., tab. 1-36. São Paulo.

- (1941): Machaerium, in Flora Brasilica 25(3): 128 e 128a: 99 p., tab. 1-107

Hutchinson, J. (1964): The genera of Flowering Plants 1. Oxford.

MACBRIDE, J. F. (1943): Leguminosae. Field Museum, Bot. Ser. 13 (3-1), Chicago: 507 p.

TAUbert, P. (1891): Leguminosae, in: Engler \& Prant,, Die natürlichen Pfanzenfamilien 3(3): 70-385, Leipzig. 